RESEARCH PAPER

\title{
A nicotine delivery device without the nicotine? Tobacco industry development of low nicotine cigarettes
}

\author{
J Dunsby, L Bero
}

Tobacco Control 2004;13:362-369. doi: 10.1136/tc.2004.007914

See end of article for authors' affiliations ......................

Correspondence to: Dr Lisa Bero, 3333 California Street, Suite 420, San Francisco, CA 92143-0613 194118 express mail only), USA; bero@medicine.ucsf.edu

Received 24 February 2004 Accepted 28 July 2004
Background: Defining harm reduction and regulating potentially reduced exposure products (PREPs), including low nicotine products, are key issues in tobacco control policy. The US Congress has been considering legislation authorising the Food and Drug Administration (FDA) to regulate tobacco products. Objective: To investigate tobacco industry perceptions, interests, motivations, and knowledge regarding the marketability of low nicotine tobacco products.

Methods: Qualitative analysis of internal tobacco industry documents identified in the Legacy Tobacco Documents Library between February 2002 and June 2004. Search terms included low-, no-, reducednicotine; denicotinization; low-, reduced- alkaloids; Next; de-nic; and key names of people, organisations, projects, and their common abbreviations and acronyms.

Results: The tobacco industry has made repeated efforts to develop low nicotine cigarettes. Reasons for doing so include consumer appeal and economic importance in a highly competitive cigarette market for "healthier" products. The industry considered the development of a new "denic" market segment a critical challenge.

Conclusions: The tobacco industry exploits consumer misunderstanding of the health effects of nicotine in development and marketing efforts. The industry has risked the development of a less addictive product to expand the market reach of tobacco products based on perceived health benefits and appeal to quitters.
$\mathrm{N}$ icotine is the basis for tobacco addiction, ${ }^{12}$ and the pharmacology of nicotine occupies a fundamental place in tobacco control. The publication of the US Surgeon General's Report, The health consequences of smoking: nicotine addiction, in 1988, focused attention on the health implications, as well as the policy implications, of treating tobacco as an addictive substance. ${ }^{1}$ Subsequently, public attention seized at times on the issue of high nicotine-and presumably more addictive-tobacco. During the mid 1990s, US policymakers, the Food and Drug Administration (FDA), and the media scrutinised the possible manipulation of nicotine levels in cigarettes. Speculation followed on whether the tobacco industry was involved in developing products to keep smokers addicted. ${ }^{3-5}$ The subsequent release of internal tobacco industry documents, moreover, affirmed that the industry considered a cigarette to be "in essence, a vehicle for delivery of nicotine" ${ }^{\prime 6}{ }^{6}$

At odds with the logic that nicotine content is essential to cigarette sales, the tobacco industry has invested substantial resources in the development of low nicotine, but not necessarily low tar, tobacco products, namely, the "Next" cigarette (Philip Morris, 1989) and the "Quest" cigarette (Vector Tobacco, 2003). These low nicotine products form part of a history of "less hazardous" cigarettes-what are now called "risk reduced" or "potentially reduced exposure products" (PREPs). ${ }^{2}$ A low nicotine cigarette alone, however, is not less hazardous. ${ }^{8}$ In response to changing consumer markets and regulatory environments, especially evolving health concerns, numerous innovations in cigarette design have been introduced in the last half century. Although public health goals shifted to cessation during the 1970s, industry research and development programmes continued on the path of PREPs. ${ }^{29-13}$

Harm reduction is one approach to reduce death and disease from tobacco use; however, smoking cessation has been the dominant strategy since the early 1980s. It is defined by the Institute of Medicine (IOM) report, Clearing the smoke: assessing the science base for tobacco harm reduction, as a product that "lowers total tobacco-related mortality and morbidity even though use of that product may involve continued exposure to tobacco-related toxicants". ${ }^{2}$ It includes a diverse and complex array of treatments and products; a recent review identified 19 approaches, ${ }^{8}$ with supporters often emphasising the centrality of nicotine pharmacology in efforts to reduce the amount an individual smokes. ${ }^{214-16}$

A wave of new products has been or is soon to be marketed, ${ }^{8}{ }^{17}$ but the public health value of harm reduction is controversial. ${ }^{2}{ }^{18-20}$ These products may not actually reduce harm; they may hinder quitting, which would be preferable, or they may encourage new smokers. In particular, reduced tar products, marketed to consumers as healthier alternatives, have been found to be just as harmful. ${ }^{12}{ }^{21-23}$ Further influencing the market for these products is the growing availability of smoking cessation products, especially, nicotine replacement products. ${ }^{24}$ The IOM Clearing the smoke monograph, industry activities, conferences, and lawsuits, have renewed attention to the issue. Notably, on 3 June 2003, Congress held hearings regarding FDA regulation of tobacco, which highlighted the public health implications of "reduced risk" products. ${ }^{25}$ Although previously opposed, Philip Morris is now publicly supporting FDA regulation of tobacco products. ${ }^{26}$ With FDA approval, tobacco companies could market their products based on health claims. Policies proposing to give FDA authority over tobacco products must contend with how to regulate the health claims of such products and how to define harm reduction in regulatory terms.

With tobacco regulation again on the public policy agenda, research on past industry activities is critical for evaluating current arguments, especially the tobacco industry's declarations of a new era of transparency and openness.

Abbreviations: ART, alkaloid reduced tobacco; FDA, Food and Drug Administration; PREPs, potentially reduced exposure products 
Furthermore, little policy research has been done on low nicotine tobacco: a recent review of tobacco harm reduction product categories has stated that the "mechanism and intention" and "regulatory status" of nicotine-free cigarettes are "unclear". ${ }^{8}$ The objective of this study is to investigate intention and rationale-that is, why has the tobacco industry invested heavily in the development of low nicotine cigarettes? Using evidence from internal documents, the study describes the tobacco industry's perceptions, interests, motivations, and knowledge regarding the marketability of low nicotine cigarettes, particularly within the USA. The focus on the tobacco industry's consumer research on low nicotine cigarettes is used to gain insight into how and why the industry might make health claims related to low nicotine tobacco, claims with important implications for regulation.

\section{METHODS}

Tobacco industry documents were retrieved from the Legacy Tobacco Documents Library Internet site (http://legacy. library.ucsf.edu), as well as industry websites and Tobacco Documents Online (http://tobaccodocuments.org/), from February 2002 to June 2004. Primary search terms were: low-, no-, reduced-nicotine; denicotinization; low-, reduced- alkaloids; Next; de-nic; and key names of people, organisations, projects, and their common abbreviations and acronyms. A "snowball" search, a selective expansion of the search based on relevant results, including searching documents filed "nearby" according to accession or Bates number, was also used. Over 7500 documents were screened for relevance to the tobacco industry's interests and rationale, with emphasis given to the most recent documents. Additional searches were conducted using the Lexis-Nexis and PubMed databases to identify relevant news stories, scientific publications, and government reports and using the Pollay advertising collection on Tobacco Documents Online to identify marketing materials. The documents were analysed inductively to identify, through repetition and context, subjective themes as well as to develop a factual narrative of events.

\section{RESULTS}

The results are organised into three sections: processes for denicotinising tobacco; Philip Morris' low nicotine-alkaloid reduced-tobacco research programme; and lastly the tobacco industry's ongoing incorporation of biotechnology into research programmes to genetically modify tobacco. We focus on Philip Morris activities for several reasons. First, Philip Morris went the furthest in commercialising a specifically low nicotine tobacco product with the exception of the very recent product introductions of Vector Tobacco. Second, and reflecting the first, the majority of documents relevant to the analysis of interests and rationale were from Philip Morris, allowing a more complete narrative to be produced. The activities of RJ Reynolds are discussed as they relate to the activities of Philip Morris. Furthermore, the technological feasibility and implications of tobacco denicotinisation processes are not evaluated; we describe research programmes to the extent that they establish a substantial commitment to, and contextualise, a new market.

\section{Denicotinised tobacco}

Attempts to remove or reduce the nicotine content of tobacco have been around for much of the history of tobacco cultivation. Plant breeding was the first method, and in the 20th century, solvents, steam, microbes, and gases have all been used to extract nicotine. In 1986, Philip Morris researchers identified over 100 patents for the denicotinisation of tobacco (table 1). Very early patent applications suggest that there was interest in removing nicotine because

\begin{tabular}{ll}
\hline Table 1 & Selected US denicotinisation patents ${ }^{110} 111$ \\
\hline Year & Patent description \\
\hline 1901 & Hydrocarbon solvent extraction \\
1908 & Superheated steam, nicotine recovery \\
1926 & Steam/ammonia, extract recombined \\
1977 & Microbial extraction \\
1979 & Supercritical gases extraction \\
1993 & Genetic modification \\
\hline
\end{tabular}

it was considered "a volatile poisonous alkaloid". ${ }^{27}$ Most recently, researchers have experimented with ways to genetically modify tobacco to block nicotine biosynthesis. None of these methods completely eliminates nicotine, but reductions have been in the range of $80-98 \%$.

Historically, nicotine has been associated with the perceived strength, or harshness, of cigarette smoke. Advertising indicates that as early as the 1930s lower nicotine was associated with a milder, less irritating taste-for example, Camels in the early 1940s and Old Gold in the 1950s. ${ }^{28}{ }^{29}$ King Sano cigarettes were the dominant and oldest brand of "denicotinised" cigarettes although they were always a small fraction of the market. With popular health concerns giving rise to filtered cigarettes in the 1950s, for a period King Sano claimed to filter the nicotine from the smoke, and also the tobacco. ${ }^{30} 31$

A 1994 report by Philip Morris reviewing the issue of denicotinisation stated: "As far back as the early 1950's through the late 1960's, Philip Morris and other companies were experimenting with various means to reduce the nicotine level of tobacco." ${ }^{132}$ The report identifies King Sano specifically and mentions it was marketed in Germany and Switzerland. Table 2 lists tobacco industry denicotinisation research programmes, dating from the late 1960s, for which evidence from the documents could be found. A 1973 RJ Reynolds report on a "No-Nicotine Project" discussed a potential market in Germany, where at the time more attention was being given to nicotine than to tar. ${ }^{33}$ The company also explored a $90 \%$ denicotinised tobacco product for the domestic market under the name "Project NL" or "project nicoless" from about 1974 to $1976{ }^{34-36}$ In 1976, Lorillard received a marketing report from Infometre on the "low nicotine concept", but did not seem to do anything further. ${ }^{37}$ By 1976, Philip Morris was explicitly examining the "smoker psychology" and pharmacological effects of low nicotine cigarettes as part of its larger psychological research efforts. ${ }^{38-40}$

\section{Alkaloid reduced tobacco (ART) programme}

As indicated in the tobacco industry documents collection, explicit discussion of marketing a low nicotine cigarette picked up again in the early 1980s, when Philip Morris started on a research programme that would lead eventually to the "Next" brand of cigarette- the name was a reference to "nicotine extracted". ${ }^{41}$ Robert Seligman, a vice president who had worked for Philip Morris in research and development for nearly 30 years, was sceptical of revisiting low nicotine tobacco. In a November 1982 response to Frank E Resnik, then president of the Tobacco Technology Group, he argued:

Anytime we conducted a consumer acceptance test, using very low nicotine-containing cigarettes, we had a great many problems maintaining our smoking population. People did not want to smoke cigarettes with a minimum of nicotine over a long period of time... From this, I am forced to conclude that a nicotine-free cigarette would be most unacceptable. ${ }^{42}$ 
Table 2 Selected low nicotine tobacco programme names identified in the documents

\begin{tabular}{|c|c|c|}
\hline Project name & Approximate dates & Notes \\
\hline \multicolumn{3}{|l|}{ Philip Morris } \\
\hline $\begin{array}{l}\text { Alkaloid Reduced Tobacco } \\
\text { (ART) }\end{array}$ & 1980s-early 1990s & Project leading to test marketing of "Next" brand \\
\hline Low Nicotine Tobacco $(\mathrm{LNT})^{90}$ & Mid 1980s-mid 1990s & $\begin{array}{l}\text { Research programme to develop low nicotine } \\
\text { tobacco primarily through genetic means }\end{array}$ \\
\hline \multicolumn{3}{|r|}{ 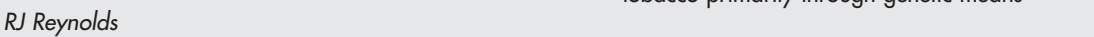 } \\
\hline No-Nicotine Project $(\mathrm{NN})^{33}$ & Early 1970s & Product development for German market \\
\hline Project Nicoless $(\mathrm{NL})^{3435}$ & $1974-1976$ & Exploration of domestic market \\
\hline $\begin{array}{l}\text { Genetically Low Alkaloid } \\
\text { Tobacco Product (GLA) }\end{array}$ & 1980 s & Agricultural research programme \\
\hline $\begin{array}{l}\text { Low Nicotine Tobacco } \\
\text { Program }{ }^{83} \text {; Nicotine } \\
\text { Reduction Program }^{83-85}\end{array}$ & 1989- & $\begin{array}{l}\text { Research and development programmes } \\
\text { rekindled following Philip Morris marketing. } \\
\text { Subprojects: Project Low Nicotine (LN); Project } \\
\text { Lowest Nicotine Available (LNA); Project Lowest } \\
\text { Nicotine Available For Marketing (LNAM) } \text { ( }^{83-85}\end{array}$ \\
\hline \multicolumn{3}{|l|}{ Vector Tobacco } \\
\hline "Quest" cigarettes 100 & Late 1990s- & $\begin{array}{l}\text { Genetically modified tobacco packaged in three } \\
\text { nicotine levels, test marketed beginning January } \\
2003\end{array}$ \\
\hline
\end{tabular}

About eight months later, a memorandum from Seligman to Resnik indicated that Philip Morris continued to give the idea of a low nicotine cigarette "serious consideration", but noted that the earlier efforts had achieved only an 80-90\% nicotine removal rate. ${ }^{43}$ Counter to Seligman's evaluation, Philip Morris executive management chose to explore-and eventually heavily invest in-a low nicotine tobacco research programme. The plan to produce alkaloid reduced tobacco (ART)—nicotine being an alkaloid-involved supercritical extraction, an adaptation of a patented process to decaffeinate coffee beans that Philip Morris acquired in 1985, when they purchased General Foods. ${ }^{32} 44$

Consumer interest and competitive pressures, primarily from RJ Reynolds, encouraged Philip Morris to develop and market a low nicotine cigarette. Evidence of consumer interest in a "healthier" cigarette is found in Philip Morris' 1985 internal new product concept study:

The concepts of most interest included cigarettes that: would have a light smoke aroma, would be nicotine free, had no ashtray odor, had a supplement (a vitamin or something to reduce tooth decay), had no visible smoke, and were ultra low tar versions... of popular full flavor brands. ${ }^{45}$ (Emphasis added)

The company's research showed what public health research later confirmed ${ }^{12}$ : the public often misunderstands the nature of nicotine by assuming it is one of the more harmful components of cigarettes. Although it is toxic in high dosages, generally smokers are not exposed at these levels, and many other components of smoke are considered a greater health risk. ${ }^{16}{ }^{47}$ The tobacco industry was aware of the consumer misconceptions from the start of the project. An earlier 1984 report on consumer interest in a possible lownicotine Merit brand found:

There is little consumer distinction between the effects of tar and nicotine, which are bracketed together in the consumer's mind. ${ }^{48}$

Recognition of consumer confusion is also found in RJ Reynolds discussions as well. ${ }^{49} 50$

In 1986, Philip Morris had further discussions about producing a denicotinised cigarette, which it was careful to keep confidential for reasons of competitive advantage. ${ }^{51-53}$ The marketing strategy aimed to build on awareness of the forthcoming Surgeon General's report on nicotine addiction ${ }^{1}$ to "launch a nicotine-extracted product with the potential of mainstream acceptance" ${ }^{54}{ }^{55}$ One handwritten comment on a product position report noted that the Surgeon General had "paved the way to provide a solution/benefit easily communicated to consumers-he's done the educating-conditioncure $^{\prime \prime 54}$ The goal appeared to be minimising nicotine only, not carcinogenic compounds, while maintaining smoking behaviour. The staff proposed experiments to gauge smokers' sensory reaction to cigarettes with half the nicotine. John Tindall-a statistical and economic analyst working on research and development issues-explained this kind of study would be easy because "smokers don't know what the sensory effects of nicotine are and the existence of lowcaffeine coffee makes the concept believable" ${ }^{56}$

Without considering health consequences, one proposal from a senior associate scientist wondered whether "it may be necessary to increase the tar" for flavour to make the nicotine trade-off acceptable to consumers. ${ }^{57}$ One group of Philip Morris scientists believed it was important to determine a "sufficient" dose to maintain smoking behaviour and still claim reduced nicotine. ${ }^{58}$ Of the proposals, Philip Morris apparently proceeded with the focus group studies that probed the relation between health and social pressures. $^{59}$ Between 1985 and 1989 Philip Morris collected responses from 2988 smokers in 11 studies. ${ }^{60}$ By 1987, a prototype cigarette was being tested. ${ }^{61}$

\section{Consumer appeal for a low nicotine cigarette}

Focus groups that reviewed marketing materials for the potential ART product demonstrated a strong interest in nonicotine products. The interest, moreover, was based on the perception that such a product would be healthier ${ }^{62-64}$ and "a way to quit smoking". ${ }^{656}$ Philip Morris conducted new product concept studies in 1983, 1985, 1987, and $1993 .{ }^{64} \mathrm{~A}$ summary of the focus groups reported:

The benefits they saw were directly linked to nicotine removal. The first was a general health benefit... Even if they didn't know exactly what nicotine and its effects were, people assumed it was bad for them. The second reason for interest was that the product would allow smokers to cut down or quit. ${ }^{67}$ 
Some smokers appeared to recognise that nicotine was addictive. Page Callaham, who worked on qualitative research for Philip Morris' Product Evaluation Division, reviewed the issue of "smokers' perception of nicotine-free cigarettes" based on Philip Morris focus group studies. In 1987, Callaham reported to Ed Gee, a director of consumer research, that some consumers might smoke more lownicotine cigarettes:

Some consumers view this product as healthier while others see it [as a way] to quit smoking. However, others commented that it would be self-defeating because they would smoke more to get the same taste satisfaction.

Consumers saw themselves as either habitual smokers or 'addicted' to nicotine. People who smoke because of a habit felt that they could adjust to the taste of a nicotinefree cigarette. ${ }^{68}$

Corroborating the earlier results, smokers from a 1989 focus group ranked the concept first because: "The cigarette would be healthier (43\%) and it would not be addictive $(24 \%)$. Also cited by $14 \%$ of the smokers was that it might be easier to quit smoking." The report identified four attitudinal groups: "resigned smoker", "proud smoker", "image smoker", and "potential quitter": "The Potential Quitter was the only group to rank Nicotine Free first." ${ }^{\prime \prime 9}$ The product seemed to appeal to older, female, and ultra low tar smokers. ${ }^{66}$ Thus, from Philip Morris' perspective, a smoker's likelihood of "quitting" was a way of segmenting the market. ${ }^{53}$ Furthermore, the marketing primarily sought to address concerns about the social pressures of smoking-those who did not "feel positive about smoking" ${ }^{\prime 66}$ or "ritual smokers" who were anxious about addiction ${ }^{70}$-rather than actual health consequences.

\section{Creating a new low nicotine market segment}

An October 1987 internal marketing analysis from Susan Alter, brand manager, to Louis Suwarna, a new products director, synthesised qualitative studies for Philip Morris' new product launch planned for late $1988 .^{71}$ The low nicotine market was assessed to have the highest potential for growth, and the report reiterated the opportunity presented by the fact that "much confusion exists in smokers' minds about the different effects of tar and nicotine...". ${ }^{71}$

The potential for quitting, however, posed a particular problem for how best to market a low nicotine product:

The potential, then, for ART is that fully one-third of smokers may perceive of ART as a useful tool for quitting. This raises the question of whether it is more desirable to have 'returning smokers' come back to established brands like Merit Ultra Lights, or B\&H Deluxe Ultra Lights, for example, or try ART. Will it be perceived as a 'lessharmful' way to continue smoking over the long-term, or a less enjoyable product which will be easier to give up, and finally quit? ${ }^{71}$

"[T]he greatest potential and challenge" for their new ART product, according to Alter, was the creation of a new market category. Because brand switching was down 15\% from 10 years before and the "new smokers to low tar" category included a high percentage of "returning" smokers, Alter reasoned that there was less growth potential in convincing smokers to switch brands than in creating a new product category that would capture "returning" smokers and "quitters". ${ }^{71}$ Moreover, the company did not believe that users of the product would actually quit but instead, according to one marketing document, "smokers will feel they can better control consumption with an ART product". ${ }^{72}{ }^{73}$ The expected market was older, female smokers "as these are the people who most often express health concerns", but also potentially "young adults who may only smoke occasionally".72 A competitive analysis by Analytic Insight, Inc, prepared for Brown \& Williamson Tobacco Corporation in January 1990, reflects this marketing logic as well. ${ }^{74}$ The economic benefit of creating a new category, a free standing brand, over the more conservative strategy of a brand line extension was reiterated in a 1989 ART planning document by David Dangoor, vice president of marketing for Philip Morris: "The most important part of this direction is that we will concentrate on 'creating' the de-nic and de-nicotined category." 75 Frank Resnik was "firmly convinced" of this strategy as well. ${ }^{76}$ In 1988, a marketing memo had estimated the potential market share of free standing denicotinised cigarette brand at $1.5-2 \%$, or "9-12 billion units". ${ }^{72}$

A document-probably from around 1992-containing the handwritten note, "John Tindall's Ryebrook presentation", provides candid insight into Philip Morris' counterintuitive decision to market low nicotine cigarettes. ${ }^{77}$ In an overview to cigarette marketing personnel, Tindall, who had a 30 year career with Philip Morris research and development, notes that a cigarette is the most effective "nicotine delivery device". In revisiting the history of the cigarette market from 1945 to 1992, he concludes that the 25 year run of the delivery segment (filters), menthol segment, and length segment-the main technological innovations that had translated into market segments-had become unproductive by 1980. The market was "saturated with brands and extensions addressing consumers' needs in the area of health perceptions by lowering tar and in the area of price through greater length". The female demographic segment was no longer growing, and the anti-smoking movement was shifting to the more effective tactic of "making smokers feel guilty about the effect smoking might have on nonsmokers around them". The concept studies, begun in the early 1980s, suggested that future success would be based less on flavour, promotion, and packaging than on providing a feature of enough perceived benefit (for example, health). In 1988, Philip Morris' eight year forecast had estimated a $2.8 \%$ per year decline in cigarette sales in the USA. ${ }^{78}$

Tindall considered the ART project in light of this market analysis:

ART was a very attractive combination of consumer need and technological capability. The consumer attraction was expected because ART addresses smokers' health concerns, and that has been the most powerful driving force in the cigarette market since 1954. What was technologically important about ART was the potential proprietary position it could give us. [p 24-25, emphasis added]

ART started out as a controversial project. We don't actually know, by direct tests, how important nicotine is in smoking, since nothing has ever been available to smoke which comes close to having just the sensory properties of tobacco, without having nicotine... Obviously, there was concern that a low-nicotine cigarette might put the cigarette industry out of business. The long-term management philosophy prevailed, though; we would compete in any category that had a chance for success. ${ }^{77}$ [p 25, emphasis added]

For reasons of competitive secrecy, Philip Morris avoided any outside market research at first. When the company 
finally did, it found "very large perceived benefits"; however, it "learned that ART also ha[d] very large sensory costs...". ${ }^{77}$ In Tindall's view, the reason was not ART's poor taste, but the sensory loss of the accustomed "throat impact" produced by nicotine. The challenge, he explained, is to "balance sensory costs and perceived health benefits". ${ }^{77}$

According to company documents, Philip Morris invested $\$ 300$ million dollars on the ART project including a new product facility, the Bermuda 100 facility, which was subsequently shutdown around 1993. A "capital appropriations request" from Frank Resnik to vice chairman, R William Murray, stated that the production plant would cost approximately \$194 million and that it would "produce twenty-one million pounds of denicotinized tobacco per year, a quantity sufficient to support the production of twelve billion cigarettes". At the time the return on investment was estimated at $20 \%{ }^{79}$ The project achieved a $95-98 \%$ reduction in nicotine ${ }^{80}$ and was marketed as a "natural" process akin to decaffeinated coffee. ${ }^{81}$ Test marketing under the new brand name "Next" began in July 1989, around the time of the release of the Surgeon General's report on nicotine addiction, in three markets (Omaha, Hartford, and Toledo). ${ }^{32} 55$ The test marketing of Philip Morris' free standing brand, Next, produced disappointing sales (less than 0.2 market share) and was withdrawn by the end of 1989 .

Notably, RJ Reynolds considered Philip Morris' efforts to be a competitive threat and revisited its own low nicotine tobacco research efforts in 1989. In the "Nicotine Reduction Program" or "Project LN", the company proposed using genetically low nicotine tobacco it had been developing in conjunction with various extraction processes to produce cigarettes of certain nicotine reductions, probably under the brand name Vantage LN. ${ }^{82-86}$ In efforts more than a decade earlier RJ Reynolds expressed the same market motivations as Philip Morris when it set the research objective of producing a reduced nicotine cigarette that would "provide the Company with a unique entry capable of establishing a new category of cigarettes". ${ }^{35}$

Additional test marketing of Next was conducted by Philip Morris in Tampa in May 1990. Beginning in October 1990, the company test marketed a reduced nicotine line extension of Benson and Hedges ("B\&H De-Nic") into 1992 (a Merit brand line extension had also been tested in August 1989). ${ }^{32}$ By 1993, a Philip Morris "concept study" found that interest in a nicotine-free cigarette had fallen in relation to other surveyed concepts-for example, a cigarette with an adjustable filter. ${ }^{64}$ Because of poor sales, Philip Morris pulled the product line from the market. Public health commentators presumed the product failed because it lacked addictive qualities $^{2}$; Philip Morris, however, offered different reasons in a document drafted for a web page: (1) very low nicotine brands were already available; and (2) poor taste. ${ }^{44} 80$

Nonetheless, Philip Morris continued to explore the potential for its technology to produce reduced nicotine cigarettes. In 1992, a report by the Operational Planning Committee, Philip Morris discussed the company's desire to develop a technology to produce a fuller flavoured, ultra low tar cigarette. The company had made some innovations in this arena with filter and paper technology that advanced this objective. Furthermore, the product market for smokers was changing. The report explained:

Several interesting things have happened both within and outside the tobacco/cigarette industry. We are seeing competition for our consumers from outside our industry, primarily from the drug industry. The "competing" products are, for example, nicotine chewing gum, nicotine patches and inhalers. ${ }^{87}$ [emphasis added]
Table 3 Philip Morris aims for genetic modification of tobacco research ${ }^{91} 92$

- Development of a no-nicotine tobacco that still had the flavour of major brands

- Reduce the formation of tobacco specific nitrosamines

- Produce experimental tobacco for subjective investigations of smoke

- Reduce the costs of nicotine disposal

- Better control nicotine content in variable agronomic conditions

Thus, the tobacco industry assessed the marketability of low nicotine cigarettes in the context of an expanded product market, including nicotine gum and patches. As corroborated by previous document research ${ }^{88}$ cigarette manufacturers competed with the drug industry to sell all kinds of nicotine products to smokers. Marketability based on health claims was the primary concern: the 1992 report described the ART technology as "a means for lowering nicotine delivery of our products while maintaining tar delivery" (emphasis added). ${ }^{87}$ As of 1994, Phillip Morris had considered test marketing a "DeNic" cigarette on the Island of St. Kitts in the Caribbean. ${ }^{89}$

The major failing of low nicotine tobacco products, according to the industry, had been their subjective taste. Research had already begun at Philip Morris to tackle these limitations and produce a low nicotine tobacco using their second strategy: genetic modification.

\section{Genetically modified tobacco}

The ART programme, with its reliance on supercritical extraction technology, was only one means of achieving low nicotine tobacco. ${ }^{90}$ A report by Philip Morris scientist, Walter Hempfling, entitled "How can biotechnology be useful to Philip Morris's cigarette business?" discussed the potential of genetic engineering for the tobacco industry as a whole, namely the "dramatic reduction of the biological activity [that is, carcinogenicity] of smoke..., elimination of tobaccospecific nitrosamines, precise control of nicotine content and delivery, reduction of carbon monoxide and stabilization and controlled release of flavorants" (emphasis added). ${ }^{91}$ Hempfling noted that earlier attempts using plant breeding had often produced inferior tobacco; presumably nicotine synthesis was genetically linked to other desirable traits. Around 1985, numerous possibilities for genetic modification were identified, as shown in table 3.

The first practical application of biotechnology by Philip Morris was, in fact, the development of low nicotine tobacco in the mid 1980s. ${ }^{91}$ First contracting to Calgene and then bringing the research in-house for reasons of competitive secrecy, Philip Morris sought to use anti-sense biotechnology to disrupt enzymes involved in nicotine biosynthesis. ${ }^{92-94}$ The available documents do not make it entirely clear how the project progressed; nonetheless, on 4 November 1997, a patent was issued to Philip Morris for an anti-sense DNA method for altering nicotine in tobacco plants. ${ }^{95}$ According to an internal email, the research programme achieved tobacco with an $80 \%$ reduction in nicotine. ${ }^{94}$ Other inventors also recognised the value of biotechnology for developing low nicotine tobacco for cigarettes that would be less addictive or that could be "used in a smoking cessation program". ${ }^{96}$

By the late 1990s Philip Morris, as well as RJ Reynolds, ${ }^{97}$ had embarked on major efforts to utilise biotechnology for commercial purposes, often with the goal of eliminating nicotine and other harmful compounds. As of 1998, documents indicate that genetically modified, low nicotine tobacco continued to receive consideration by Philip Morris. ${ }^{98}$ Although the current status of the Phillip Morris low nicotine research programme is unclear, its history is still relevant to settling FDA authority over tobacco products. 
Furthermore, in January 2003, Vector Tobacco, the smallest of the five major tobacco companies, began to market a new cigarette, "Quest", that is produced from tobacco genetically modified to contain only trace amounts of nicotine ${ }^{99}$ and that is all but marketed as a smoking cessation device. ${ }^{100-103}$

\section{DISCUSSION}

Although counter to the conventional logic that the profitability of cigarettes depends on the addictive qualities of nicotine, the tobacco industry pursued, since at least the 1950s, the development of a presumably less addictive product. The explanation is exploitation of consumer misconceptions about nicotine and product diversification in a changing cigarette market.

Philip Morris played on consumer ignorance in its marketing strategy, and the industry's timing was intended to take advantage of the awareness of nicotine's addictive properties produced by the 1988 Surgeon General's report. ${ }^{1548}$ As the internal industry documents show, their goal was to make a reduced nicotine health claim, even if other harmful components were increased.

In the context of a saturated low tar cigarette market, low nicotine cigarettes were an attempt to market to consumer health concerns. The tobacco companies sought to define and lead a new market for "healthier" cigarettes that might appeal to "quitters". For industry management, the risk that low nicotine cigarettes might put the industry "out of business" was outweighed by the benefit of creating a new market segment. The highly competitive and secretive research and development efforts, including a long term commitment to genetic research, are evidence of the economic importance of this new market to the tobacco industry. The documents suggest that the tobacco industry is developing these products to maintain profitability, not protect health. Thus, the industry's motives for developing and gaining acceptance for a new segment of "harm reduced" products are different than the interests of the public health community. Furthermore, our findings suggest the need for an external body to review product claims and to be particularly cautious about claims that may confuse consumers.

Our study has several limitations. First, we cannot be sure that we have identified all documents on our topic. Furthermore, time and financial constraints do not allow all depositories and websites to be comprehensively investigated, ${ }^{104}$ and additional documents are still being added. Nonetheless, numerous analyses have shown that the tobacco industry documents offer unprecedented insights into the industry's motives, interests and knowledge. ${ }^{105}$

The tobacco industry is remaking its image, and the concept of harm reduction is its rallying cry. By discussing its current developments for PREPs, it hopes to live up to its purported goal of transparency. ${ }^{106}$ Following the release of the IOM report and the accompanying media attention, Philip Morris lawyers drafted a series of message points to be used by employees emphasising the company's commitment to "the development of cigarettes that have the potential to reduce the harm caused by smoking" and a "rational" regulatory environment that respects "the principle of adult

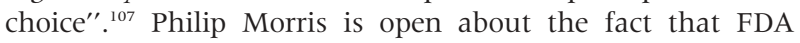
regulation would now benefit the company because only with FDA approval can the industry make health claims about tobacco products ${ }^{26}$ :

We believe FDA regulation would provide greater consistency in tobacco policy, more predictability for the tobacco industry and an effective way to address issues that are of concern to our Company and society. ${ }^{108}$

\section{What this paper adds}

The issue of tobacco harm reduction has recently received increased interest among tobacco researchers, policymakers, and the tobacco industry. Tobacco products that claim to reduce the risks of smoking are controversial because product effectiveness is uncertain and marketing practices are questioned. Attempts to regulate tobacco in the USA are dependent on resolving regulatory issues related to harm reduction.

The tobacco industry documents provide insight into the motivations, interests, and strategies of the tobacco industry in developing low nicotine products. This source of data explains why a low nicotine product is not a contradiction to tobacco industry interests. Previous document research has focused primarily on the issue of low tar cigarettes. By examining this atypical product, but one that the tobacco industry has invested heavily in, we better understand the overall market development of tobacco products that claim to be less harmful. The industry's development of low nicotine products has been market rather than health driven.

The industry knows that without the public trust embedded in FDA approval, its health claims, which could lead to greater market shares, will be dismissed and criticised. While it is too early to evaluate the genuineness and form of the new industry openness, past activities suggest that health claims will be based on perceived rather than actual health benefits. Earlier institutional cultures and organisation objectives tend to persist well into a change of rhetoric. ${ }^{109}$

\section{ACKNOWLEDGEMENTS}

California Tobacco-Related Disease Research Program Grant 9RT0193 and the Legacy Foundation provided research support. The authors wish to thank Pam Ling for research materials and the Institute for Health Policy Studies writing group for comments on a draft of this paper.

\section{Authors' affiliations}

J Dunsby, Center for Tobacco Control Research and Education, University of California, San Francisco, USA

L Bero, Department of Clinical Pharmacy, Institute for Health Policy Studies, Center for Tobacco Control Research and Education, University of California, San Francisco, USA

\section{REFERENCES}

1 US Department of Health and Human Services. The health consequences of smoking: nicotine addiction, A report of the Surgeon General, 1988. Rockville, Maryland: Public Health Service, Centers for Disease Control, Office on Smoking and Health, 1988, (DHHS Publication No (CDC) 888406.).

2 Stratton K, Shetty P, Wallace R, Bondurant S, Committee to Assess the Science Base for Tobacco Harm Reduction, Institute of Medicine, eds. Clearing the smoke: assessing the science base for tobacco harm reduction. Washington DC: National Academy Press, 2001.

3 Hilts PJ. Smokescreen: the truth behind the tobacco industry cover-up. Reading, Massachusetts: Addison-Wesley, 1996.

4 Douglas CE. Taking aim at the bull's-eye: the nicotine in tobacco products. Tobacco Control 1998;7:215-18.

5 Kessler D. A question of intent: a great American battle with a deadly industry. New York: Public Affairs, 2001.

6 Teague CE Jr. Research planning memorandum on the nature of the tobacco business and the crucial role of nicotine therein. April 14, 1972. RJ Reynolds Collection. Bates No. 500898378/500898386. http:// legacy.library.ucsf.edu/tid/nnv59d00 [Accessed 21 May 2003].

7 Slade J, Bero LA, Hanaver P, et al. Nicotine and addiction: The Brown and Williamson documents. JAMA 1995;274:225-33.

8 Shiffman S, Gitchell JG, Warner KE, et al. Tobacco harm reduction: conceptual structure and nomenclature for analysis and research. Nicotine Tob Res 2002;4(suppl 2):S1 13-29.

9 Glantz SA, Slade J, Bero LA, et al. The cigarette papers. Berkeley: University of California Press, 1996 
10 Gori GB. Virtually safe cigarettes: reviving an opportunity once tragically rejected, Amsterdam \& Washington, D.C. : IOS Press \& Ohmsha, 2000.

11 Hoffmann D, Hoffmann I, El-Bayoumy K. The less harmful cigarette: a controversial issue. A tribute to Ernst L. Wynder. Chem Res Toxicol 2001;14:767-90.

12 National Cancer Institute. Risks associated with smoking cigarettes with low machine-measured yields of tar and nicotine. Smoking and Tobacco Control Monograph No. 13. Bethesda, Maryland: US Department of Health and Human Services, Public Health Service. National Institutes of Health. National Cancer Institute; October 2001. (NIH Publication No. 02-5047).

13 Wayne GF, Connolly GN. How cigarette design can affect youth initiation into smoking: Camel cigarettes 1983-93. Tobacco Control 2002;11(uppl 1):132-9.

14 Benowitz NL, Henningfield JE. Establishing a nicotine threshold for addiction. The implications for tobacco regulation. N Engl J Med July 14, 1994;331:123-5.

15 Henningfield JE, Benowitz NL, Slade J, et al. Reducing the addictiveness of cigarettes. Tobacco Control 1998;7:281-93.

16 Benowitz NL. Smoking less as a treatment goal for those who cannot stop smoking. Am J Med 2004; 116:203-5.

17 New tobacco products: truth and consequences. Burning Issues, TRDRG Newsletter Vol 5 2002:1-6.

18 Warner KE. Tobacco harm reduction: promise and perils. Nicotine Tob Res 2002;4(suppl 2):S61-71.

19 Pierce JP. Harm reduction or harm maintenance? Nicotine Tob Res 2002;4(suppl 2):S53-4.

20 Fox BJ, Cohen JE. Tobacco harm reduction: a call to address the ethical dilemmas. Nicotine Tob Res 2002;4(suppl 2):S81-7

21 Kozlowski LT, Goldberg ME, Yost BA, et al. Smokers' misperceptions of light and ultra-light cigarettes may keep them smoking. Am J Prev Med 1998;15:9-16.

22 Pollay RW, Dewhirst T. The dark side of marketing seemingly "Light" cigarettes: successful images and failed fact. Tobacco Control 2002;1 1/suppl I):i18-31.

23 Farone WA. Harm reduction: 25 years later. Tobacco Control 2002:11:287-8.

24 Warner KE, Slade J, Sweanor DT. The emerging market for long-term nicotine maintenance. JAMA 1997;278:1087-92.

25 Committee on Government Reform. Special Investigations Division. The lessons of "light" and "low tar" cigarettes: Without effective regulation "reduced risk" tobacco products threaten the public health, Washington DC: US House of Representatives; June 3, 2003.

26 Szymanczyk M. Written statement of Mike Szymanczyk, Chairman and Chief Executive Officer, Philip Morris USA. Submitted to the Committee on Government Reform. June 3, 2003. Philip Morris USA. http:// www.philipmorrisusa.com/pressroom/ [Accessed 4 June 2003]

27 Smith H. United States Patent Office 1,577,768: Tobacco denicotinization March 23, 1926. Phillip Morris Collection. Bates No. 2026381972/ 2026381974. http://legacy.library.ucsf.edu/tid/elz85e00 [Accessed 6 March 2003]

28 RJ Reynolds. The smoke's the thing! [Camel cigarette advertisement in Saturday Evening Post]. 1941. Pollay Advertising Collection. http:// tobaccodocuments.org/pollay_ads/Came50.09.html [Accessed 14 June 2004].

29 Lorillard. No medical blarney [Old Gold cigarette advertisement]. 1950. Pollay Advertising Collection. http://tobaccodocuments.org/pollay_ads/ Oldg03.07.html [Accessed 14 June 2004].

30 U. S. Tobacco Co. Smoke a lot? Then think before you choose your brand [Advertisement for King Sano cigarettes in Time magazine]. 1956. Pollay Advertising Collection. No. http://tobaccodocuments.org/pollay_ads/ King01.03.html [Accessed 14 June 2004].

31 N. A. Good Housekeeping Magazine. Denicotinized cigarettes - How good are they? April 1957. Tobacco Institute Collection. Bates No. TIMN0300971/0300972. http://legacy.library.ucsf.edu/tid/qyl62f00 [Accessed 14 June 2004]

32 N. A. Philip Morris USA. Alkaloid Reduced Tobacco (ART) Program. September 1, 1994. Bates No. 2057908259-2057908291. http:// tobaccodocuments.org/product_design/2057908259-8291.html [Accessed 14 June 2004

33 Hansen J, Muller J. Report on no-nicotine project. May 10, 1973. R.J. Reynolds Collection. Bates No. 509386784/509386801. http:// legacy.library.ucsf.edu/tid/gbn73d00 [Accessed 3 March 2003]

34 Wooten S Jr. R.J. Reynolds. Project NL [Memo to CW Fitzgerald]. November 21, 1974. R.J. Reynolds Collection. Bates No. 500254017. http:// legacy.library.ucsf.edu/tid/xki89d00 [Accessed 19 March 2003].

35 Fitzgerald C. R. J. Reynolds. Product development request - 'NL' [Memo to RH Cundiff]. December 6, 1974. R. J. Reynolds Collection. Bates No. 500742037. http://legacy.library.ucsf.edu/tid/hrl69d00 [Accessed 19 March 2003].

36 Alter S. Philip Morris USA. Trademark searches: All-natural and nicotine free, November 11, 1987. Philip Morris Collection. Bates No. 2045407566. http://legacy.library.ucsf.edu/tid/smi87e00 [Accessed 6 March 2003]

37 Infometre Group. Low Nicotine Concept Focus Discussion Groups. September, 1976. Lorillard Collection. Bates No. 84053754/84053781 http://legacy.library.ucsf.edu/tid/eru4le00 [Accessed 19 March 2003]

38 Dunn WLJ, Levy C, Ryan F. Philip Morris. Smoker psychology behavioral research annual report. June 13, 1977. Philip Morris Collection. Bates No. 2024545564/2024545594. http://legacy.library.ucsf.edu/tid/wwi44e00 [Accessed 3 March 2003].

39 Ryan FJ, Dunn WU. Philip Morris USA. Special report. Exit brand cigarettes: A study of ex-smokers, Smoker psychology. March 1978. Philip Morris
Collection. Bates No. 2024546975/2024546997. http://

legacy.library.ucsf.edu/tid/ggw58e00 [Accessed 3 March 2003]

40 Osdene T. Philip Morris USA. Nicotine Program [Memo to RB Seligman]. December 1, 1978. Philip Morris Collection. Bates No. 2024545394/ 2024545401. http://legacy.library.ucsf.edu/tid/qxv58e00 [Accessed 3 March 2003]

41 Bonhomme J, Lalley C, Levy C, Leo Burnett Agency, et al. Leo Burnett Agency. Marketing research department report: Qualitative research on ART, October 17, 1988. Philip Morris Collection. Bates No. 2023088868/ 2023088871. http://legacy.library.ucsf.edu/tid/opc68e00 [Accessed 6 March 2003].

42 Seligman RB. Philip Morris Incorporated. Nicotine free cigarettes. November 22, 1982. Philip Morris Collection. Bates No. 1003724213. http:// legacy.library.ucsf.edu/tid/gqp08e00 [Accessed 6 March 2003].

43 Seligman RB. Philip Morris USA. Nicotine free cigarettes. July 27, 1983. Philip Morris Collection. Bates No. 2024545084. http:// legacy.library.ucsf.edu/tid/iaw58e00 [Accessed 6 March 2003].

44 N. A. Philip Morris. Philip Morris developments: The denicotinized tobacco story, 1999/E. Philip Morris Collection. Bates No. 2078425524/ 2078425540. http://legacy.library.ucsf.edu/tid/xap75c00 [Accessed 6 March 2003].

45 Goodale $\Pi$. Philip Morris. R\&D new products meeting -Tuesday 860107. January 15, 1986. Philip Morris Collection. Bates No. 2024944128/ 2024944130. http://legacy.library.ucsf.edu/tid/iiw88e00 [Accessed 6 March 2003].

46 Benowitz NL, Gourlay SG. Cardiovascular toxicity of nicotine: implications for nicotine replacement therapy. J Am Coll Cardiol 1997;29:1422-31.

47 Hecht SS, Murphy SE, Carmella SG, et al. Effects of reduced cigarette smoking on the uptake of a tobacco-specific lung carcinogen. J Natl Cancer Inst 2004;96:107-15.

48 Poole G, Alden A, Cappelletti K. Leo Burnett Agency. 97 percent nicotinefree for MUL. December 28, 1984. Philip Morris Collection. Bates No. 2045609296/2045609298. http://legacy.library.ucsf.edu/tid/fmo92e00 [Accessed 6 March 2003].

49 McCaffrey K. Now line extension concept - reduced nicotine [Memo to DN lauco]. March 26, 1986. R. J. Reynolds Collection. Bates No. 505512989/ 50551 2989. http://legacy.library.ucsf.edu/tid/den15d00 [Accessed 19 March 2003]

50 Teague S. R.J. Reynolds. Low/No nicotine project. August 17, 1988. R.J. Reynolds Collection. Bates No. 507189283/507189283. http:// legacy.library.ucsf.edu/tid/awm54d00 [Accessed 3 March 2003].

51 Martin P. Philip Morris USA. Low nicotine cigarette. May 12, 1986. Philip Morris Collection. Bates No. 2057760724. http://legacy.library.ucsf.edu/ $\mathrm{tid} /$ fvu96e00 [Accessed 6 March 2003]

52 Wu L. Philip Morris USA. Proposal for focus groups to investigate low nicotine cigarettes. May 20, 1986. Philip Morris Collection. Bates No. 2001260267. http://legacy.library.ucsf.edu/tid/yea88e00 [Accessed 6 March 2003].

53 Jones J. Philip Morris USA. Attitude research on low nicotine cigarettes. May 29, 1986. Philip Morris Collection. Bates No. 2001260265/2001260266. http://legacy.library.ucsf.edu/tid/xea88e00 [Accessed 6 March 2003]

54 N. A. Project Art. 1986/E. Philip Morris Collection. Bates No. 2021337098/2021337106. http://legacy.library.ucsf.edu/tid/avh98e00 [Accessed 21 March 2003]

55 N. A. Project ART test marketing plan. July, 1989. Philip Morris Collection. Bates No. 2023086420/2023086457. http://legacy.library.ucsf.edu/tid/ cab44e00 [Accessed 3 March 2003].

56 Tindall J. Philip Morris USA. Low-nicotine concept and sensory testing. May 27, 1986. Philip Morris Collection. Bates No. 2001260268/2001260270. http://legacy.library.ucsf.edu/tid/oea88e00 [Accessed 6 March 2003].

57 Ryan F. Philip Morris. Nicotine-free testing proposal. June, 1986/E. Philip Morris Collection. Bates No. 2001260257/2001260264. http:// legacy.library.ucsf.edu/tid/wea88e00 [Accessed 6 March 2003].

58 Jeltema M. Philip Morris USA. Testing denicotinized cigarettes. June 10 1986. Philip Morris Collection. Bates No. 2001260246/2001260247. http://legacy.library.ucsf.edu/tid/whx74e00 [Accessed 6 March 2003].

59 Martin P. Philip Morris USA. The appeal of a low-nicotine cigarette to the consumer. May 19, 1986. Philip Morris Collection. Bates No. 2057760706/ 2057760707. http://legacy.library.ucsf.edu/tid/Ink52e00 [Accessed 6 March 2003]

60 N. A. Low-nicotine exploratory research. March, 1990/E. Philip Morris Collection. Bates No. 2023349778/2023349785. http:// legacy.library.ucsf.edu/tid/zfo44e00 [Accessed 19 March 2003]

61 Martin P. Philip Morris USA. Proposed testing of ART cigarette. April 29, 1987. Philip Morris Collection. Bates No. 2057746027/2057746028. http://legacy.library.ucsf.edu/tid/hlo86e00 [Accessed 6 March 2003]

62 Bamundo Qualitative Research. A qualitative exploration designed to gain insights into the appeal of a 97 percent nicotine-free cigarette. December 1987. Philip Morris Collection. Bates No. 2023087252/2023087283. http://legacy.library.ucsf.edu/tid/dmt71f00 [Accessed 6 March 2003].

63 Post S, Kuhn F. Philip Morris USA. Freeport/N-ext in-depth interviews. March 2, 1988. Philip Morris Collection. Bates No. 2023088294/ 2023088297. http://legacy.library.ucsf.edu/tid/mtf44e00 [Accessed 6 March 2003]

64 N. A. Philip Morris U.S.A. Concept study. 1997/E. Philip Morris Collection Bates No. 2075649788/2075649802. http://legacy.library.ucsf.edu/tid/ chi55c00 [Accessed 6 March 2003]

65 N. A. Nicotine-free cigarette. 1985/E. Philip Morris Collection. Bates No. 2001260292. http://legacy.library.ucsf.edu/tid/jea88e00 [Accessed 6 March 2003]. 
66 N. A. Nicotine Concept Test. February, 1988. Philip Morris Collection. Bates No. 2045723380/2045723427. http://legacy.library.ucsf.edu/tid/ all75e00 [Accessed 19 March 2003].

67 Bonhomme J, Lalley C, Levy C, Stamel N. Leo Burnett Agency. Marketing research department report: Qualitative research on ART, October 17, 1988. Philip Morris Collection. Bates No. 2023088868/2023088871 http://legacy.library.ucsf.edu/tid/opc68e00 [Accessed 6 March 2003].

68 Callaham P. Philip Morris USA. Review of smokers' perception of nicotine free cigarette. September 15, 1987. Philip Morris Collection. Bates No. 2057104090/2057104091. http://legacy.library.ucsf.edu/tid/add52e00 [Accessed 6 March 2003].

69 N. A. Philip Morris. Nicotine free concept test (discussion draft). 1989/E. Philip Morris Collection. Bates No. 2045737946/2045738012. http:// legacy.library.ucsf.edu/tid/jtll6e00 [Accessed 6 March 2003].

70 N. A. Project ART CRC. February 22, 1989. Philip Morris Collection. Bates No. 2041360308/2041360316. http://legacy.library.ucsf.edu/tid/ wbj05e00 [Accessed 3 March 2003].

71 Alter S. Philip Morris U.S.A. ART marketing overview. October 9, 1987. Philip Morris Collection. Bates No. 2023086633/2023086651. http:// legacy.library.ucsf.edu/tid/ykn68e00 [Accessed 6 March 2003].

72 N. A. Project ART: Q \& A - Marketing, February 22, 1988. Philip Morris Collection. Bates No. 2023086626/2023086629. http:// legacy.library.ucsf.edu/tid/eln68e00 [Accessed 3 March 2003].

73 Eisen K. Philip Morris USA. Next extended use test - partial topline. July 25, 1989. Philip Morris Collection. Bates No. 2023086419. http:// legacy.library.ucsf.edu/tid/rln68e00 [Accessed 3 March 2003].

74 Analytic Insight. Low nicotine cigarettes: Competitive concept and advertising evaluation. January 3, 1990. Brown and Williamson Collection. Bates No. 670804470/670804492. http://legacy.library.ucsf.edu/tid/ gfs03f00 [Accessed 6 March 2003].

75 Dangoor DE. Philip Morris USA. [Memo to Peter Volz, Leo Burnett Agency, regarding ART project]. March 20, 1989. Philip Morris Collection. Bates No. 2023086570/2023086573. http://legacy.library.ucsf.edu/tid/mln68e00 [Accessed 3 March 2003].

76 Resnik FE. Philip Morris USA. Project ART [Memo to RW Murray]. March 9, 1989. Philip Morris Collection. Bates No. 2023263325/2023263326. http://legacy.library.ucsf.edu/tid/qwh46e00 [Accessed 3 March 2003]

77 Tindall JE. Philip Morris. Cosmic: History of tobacco use benefits, costs, and social influences, 1992/E. Philip Morris Collection. Bates No. 2023768423/ 2023768483. http://legacy.library.ucsf.edu/tid/pdq98e00 [Accessed 3 March 2003].

78 Weinstein B, Marketing Research Department. Philip Morris U.S.A. Eight year forecast - P.M. - U.S.A. February 10, 1988, 1988. Philip Morris Collection. Bates No. 20451 18227/20451 18228. http:// legacy.library.ucsf.edu/tid/oeg03e00 [Accessed 3 March 2003]

79 Resnik FE. Phillip Morris U.S.A. Capital appropriation request: alkaloid reduced tobacco process facility, February 11, 1988. Philip Morris Collection. Bates No. 2023087170/2023087171. http:// legacy.library.ucsf.edu/tid/bin68e00 [Accessed 3 March 2003].

80 N. A. The "denicotinized" cigarette. N.D., 1999/E. Philip Morris Collection Bates No. 2083480351. http://legacy.library.ucsf.edu/tid/rsy55c00 [Accessed 6 March 2003].

81 Hartwell RV. Project ART - 'Natural' process. March 29, 1989. Philip Morris Collection. Bates No. 2023088650. http://legacy.library.ucsf.edu/ $\mathrm{tid} / \mathrm{mrc68e00}$ [Accessed 3 March 2003].

82 Vellegas EH. R.J. Reynolds. Comparison of genetically low nicotine tobaccos with denicotinized tobacco. January 7, 1983. R.J. Reynolds Collection. Bates No. 501660695/501660704. http://legacy.library.ucsf.edu/tid/ xbl39d00 [Accessed 3 March 2003].

83 N. A. Low/no-nicotine. February 6, 1989. R.J.Reynolds Collection. Bates No. 507063309/507063332. http://legacy.library.ucsf.edu/tid/ oan34d00 [Accessed 3 March 2003].

84 Hoult PJ. R.J.Reynolds. RJR response to Philip Morris "no-nicotine" introduction. June 28, 1989. R.J. Reynolds Collection. Bates No. 507135657/507135658. http://legacy.library.ucsf.edu/tid/kzg34d00 [Accessed 3 March 2003].

85 Stewart J. R.J. Reynolds. Nicotine Reduction Program. January 11, 1990. R.J.Reynolds Collection. Bates No. $511514649 / 511514670$. http:// legacy.library.ucsf.edu/tid/bet43d00 [Accessed 3 March 2003].

86 N. A. LN fact book. December, 1991. R.J. Reynolds Collection. Bates No. 510355011/510355030. http://legacy.library.ucsf.edu/tid/oof63d00 [Accessed 14 June 2003]

87 Philip Morris. Operational Planning Committee (New Products). 1992. Philip Morris Collection. Bates No. 2021385262/2021385477. http:// legacy.library.ucsf.edu/tid/wts02a00 [Accessed 3 March 2003].

88 Shamasunder B, Bero LA. Financial ties and conflicts of interest between pharmaceutical and tobacco companies. JAMA 2002;288:738-44.
89 Yatrakis GN. Philip Morris USA. De-Nic Cigarette Production. October 1, 1994. Philip Morris Collection. Bates No. 2057763005/2057763006. http://legacy.library.ucsf.edu/tid/sbz83c00 [Accessed 3 March 2003].

90 N. A. Low nicotine product program. 1986/E. Philip Morris Collection. Bates No. 2075629866/2075629874. http://legacy.library.ucsf.edu/tid/ xti37d00 [Accessed 6 March 2003].

91 Hempfling W. Philip Morris. Philip Morris and the "new biotechnology". October 9, 1987. Philip Morris Collection. Bates No. 2024837696/ 2024837704. http://legacy.library.ucsf.edu/tid/pgo68e00 [Accessed 3 Feb 2003].

92 Hempfling W. Philip Morris USA. Justification of low-nicotine tobacco (LNT) project with Calgene, Inc. November 11, 1985. Philip Morris Collection. Bates No. 2024944558. http://legacy.library.ucsf.edu/tid/diw88e00 [Accessed 3 Feb 2003].

93 Goodale TT. Philip Morris USA. PM-USA products committee meeting August 7, 1986. August 7, 1986. Philip Morris Collection. Bates No. 2024944161/2024944163. http://legacy.library.ucsf.edu/tid/rwe34e00 [Accessed 6 March 2002].

94 Ellis C. Philip Morris. [Associated Press inquiry regarding increased nicotine]. November 13, 1997. Philip Morris Collection. Bates No. 2072388928B/2072388929. http://legacy.library.ucsf.edu/tid/ epn27d00 [Accessed 6 March 2002].

95 Venable MB. Philip Morris Management Corporation. Notification of issuance of US patent. November 26, 1997. Philip Morris Collection. Bates No. 2060531727. http://legacy.library.ucsf.edu/tid/zel13e00 [Accessed 6 March 2002].

96 Sensa. [Sensa Business Plan] Executive Summary. April 4, 1992. R.J. Reynolds Collection. Bates No. 515600200/515600203. http:// legacy.library.ucsf.edu/tid/wyr92d00 [Accessed 6 March 2002]

97 Davis L. R.J. Reynolds. Program/ Project Resource Sheet. Project LNA (GLA). 1989. R.J. Reynolds Collection. Bates No. $511243168 / 511243170 . \mathrm{http}: / /$ legacy.library.ucsf.edu/tid/qrd53d00 [Accessed 3 March 2002].

98 Gadani F. Philip Morris Europe. Minutes of the 6th TBWG meeting, Richmond, 981119 - 981120 . November 27, 1998. Philip Morris Collection. Bates No. 2073337146/2073337152. http:// legacy.library.ucsf.edu/tid/vxz27d00 [Accessed 6 March 2002]

99 Vector Tobacco. Our breakthroughs: Virtual elimination of nicotine. www.vectortobacco.com/concepts.asp [Accessed 22 Nov 2002].

100 Fisher B. Safeguarding smokers: Vector Tobacco will employ new methods to reduce carcinogenic compounds in smoke and to eliminate nicotine. Tobacco Reporter 2001 (March).

101 Dalesio EP. Vector Tobacco's new nicotine-reduced cigarettes reach market. Associated Press January 27, 2003;Domestic News.

102 Vector Tobacco. Quest cigarettes. www.questcigs.com [Accessed $10 \mathrm{Dec}$ 2002].

103 Myers ML. Vector's claims about 'nicotine-free' cigarettes underscore Congress' need to grant FDA authority over all tobacco products. U.S. Newswire January 27, 2003.

104 Malone RE, Balbach, eds. Tobacco industry documents: treasure trove or quagmire? Tobacco Control 2000;9:334-8.

105 Bero L. Implications of the tobacco industry documents for public health and policy. Annu Rev Public Health 2003;24:267-88.

106 N. A. The reduced-risk cigarette. 2001/E. Philip Morris Collection. Bates No. 2505614430. http://legacy.library.ucsf.edu/tid/uwe90c00 [Accessed 19 March 2003]

107 Philip Morris. Philip Morris USA and Philip Morris International: Working with governments and the public health community to develop and responsibly market potentially "reduced risk" tobacco products. April 27, 2001. Philip Morris Collection. Bates No. $2085273501 / 2085273507$. http://legacy.library.ucsf.edu/tid/bzk10c00 [Accessed 21 March 2003].

108 Philip Morris USA. Policies, practices, and positions. www.philipmorrisusa.com [Accessed 5 June 2003].

109 Cummings KM, Morley CP, Hyland A. Failed promises of the cigarette industry and its effect on consumer misperceptions about the health risks of smoking. Tobacco Control March, 2002;11 (suppl I):i1 10-17.

110 N. A. US and foreign patent references: denicotinization of tobacco, August 4, 1986. Philip Morris Collection. Bates No. 2025620092/2025620109. http://legacy.library.ucsf.edu/tid/doc46e00 [Accessed 6 March 2003].

111 U. S. Patents and Trademark Office. Patent full text database. http:// www.uspto.gov/ [Accessed 13 May 2003]

112 N. A. Project ART: Alkaloid reduced tobacco, 1986/E. Philip Morris Collection. Bates No. 2021559573/2021559616. http:// legacy.library.ucsf.edu/tid/ene58e00 [Accessed 3 March 2003]

113 N. A. LNT project - Recommendation at 1/88. January, 1988. Philip Morris Collection. Bates No. 2028607909/2028607912. http:// legacy.library.ucsf.edu/tid/fzi25e00 [Accessed 6 March 2003]. 